\title{
Isolasi dan Identifikasi Bakteri Pendegradasi Styrofoam asal Tanah Tempat Pembuangan Akhir Sarimukti Bandung
}

\author{
Tri Rahayu Hidayat ${ }^{1)}$, Ida Indrawati ${ }^{2)}$ Tati Herlina $^{3)}$ \\ ${ }^{1}$ Program Studi Biologi, Fakultas Matematika dan Ilmu Pengetahuan Alam, Universitas Padjadjaran \\ email: tri13011@mail.unpad.ac.id \\ ${ }^{2}$ Program Studi Biologi, Fakultas Matematika dan Ilmu Pengetahuan Alam, Universitas Padjadjaran \\ email: ida.indrawati@unpad.ac.id \\ ${ }^{3}$ Program Studi Kimia, Fakultas Matematika dan Ilmu Pengetahuan Alam, Universitas Padjadjaran \\ email: tati.herlina@unpad.ac.id
}

APA Citation: Hidayat, T,R.., Indrawati, I., \& Herlina, T. (2020). Isolasi dan Identifikasi Bakteri Pendegradasi Styrofoam asal Tanah Tempat Pembuangan Akhir Sarimukti Bandung. Quagga: Jurnal Pendidikan dan Biologi, 12(2), 110-116. doi: 10.25134/quagga.v12i2.2353.

Received: 01-010-2020

Accepted: 21-06-2020

Published: 01-07-2020

\begin{abstract}
Abstrak: Styrofoam adalah jenis plastik yang sering dimanfaatkan oleh masyarakat, terutama untuk tempat makanan atau minuman. Limbah kemasan styrofoam dapat membebani alam karena sulit terurai dan dapat menyebabkan berbagai penyakit bagi manusia karena adanya migrasi benzena dari kemasan styrofoam ke makanan. Metode pengolahan limbah styrofoam yang bisa digunakan adalah dengan mencari bakteri yang secara alami dapat mendegradasi styrofoam. Bakteri yang teradaptasi untuk mendegradasi polimer sintetik salah satunya adalah bakteri yang berasal dari Tempat Pembuangan Akhir. Tujuan penelitian ini adalah untuk mendapatkan jenis bakteri pendegradasi styrofoam secara alami. Penelitian ini menggunakan metode eksploratif deskriptif yang terdiri atas tahapan uji biodegradasi dengan metode Kolom Winogradsky, isolasi dengan teknik pour plate dan identifikasi bakteri pendegradasi styrofoam. Hasil yang didapat pada penelitian ini terdapatnya biofilm bakteri yang tumbuh di permukaan Styrofoam. Hasil isolasi dan identifikasi bakteri didapatkan 4 spesies bakteri pendegradasi styrofoam, yaitu B. amyloliquefaciens, B. cereus, B. firmus dan P. aeruginosa. Hasil dari penelitian ini dapat direkomendasikan untuk dikembangkan sebagai metode untuk mengurangi limbah styrofoam yang ramah lingkungan.
\end{abstract}

Kata Kunci: Bakteri; Degradasi; Styrofoam, Tempat Pembuangan Akhir, Isolasi.

\begin{abstract}
Styrofoam is the plastic type that are often used by the community, especially for food or drink. Styrofoam packaging waste can overload in nature because it is difficult to decompose and can cause various diseases for human due to the migration of benzene from styrofoam packaging to food. The styrofoam waste treatment method that can be used is to look for bacteria that can naturally degrade styrofoam. Bacteria that are adapted to degrade synthetic polymers are bacteria from the Final Disposal Site. The purpose of this study was to obtain the type of styrofoam degrading bacteria naturally. This research uses descriptive exploratory method which consists of biodegradation test stages with the Winogradsky Column method, isolation with pour plate technique and identification of styrofoam degrading bacteria. The results obtained in this study were the presence of bacterial biofilms that grew on the surface of styrofoam. The results of isolation and identification of bacteria obtained 4 species of Styrofoam degrading bacteria, are B. amyloliquefaciens, B. cereus, B. firmus and P. aeruginosa. The results of this study can be recommended to be developed as a method to reduce environmentally friendly styrofoam waste.
\end{abstract}

Keywords: Bacteria, Degradation, Styrofoam, Final Disposal Site, Isolation.

\section{PENDAHULUAN}

Styrofoam banyak digunakan dalam berbagai keperluan, misalnya sebagai pelindung bahan elektronik bahkan untuk bahan pengemas makanan atau minuman. Limbah ini tidak hanya memiliki dampak negatif bagi lingkungan, namun berdampak negatif untuk kesehatan manusia. Styrofoam yang digunakan sebagai bahan pengemas makanan atau minuman terbentuk atas stirena dan benzena, penyakit bisa timbul akibat migrasi benzena dari bahan pengemas ke makanan yang dikonsumsi. Benzena dapat menyebabkan kerusakan kelenjar tiroid, menganggu sistem syaraf, meningkatkan 
aktivitas detak jantung, kesulitan untuk tidur, mudah gelisah bahkan dapat berakibat kematian. Saat benzena masuk ke sistem pencernaan dan masuk ke dalam eritrosit maka pada akhirnya akan merusak sumsum tulang belakang sehingga menyebabkan produksi eritrosit berkurang dan menyebabkan anemia. Efek lain dari migrasi benzena ini akan mengganggu sistem imun sehingga menjadi mudah terinfeksi. Zat ini berakibat tidak baik pada wanita karena dapat merusak siklus menstruasi dan kehamilan. Efek yang paling berbahaya, zat ini bisa menyebabkan kanker payudara dan kanker prostat (Sulchan, 2007).

Styrofoam merupakan polistirena yang termasuk ke dalam golongan plastik nomor 6 dalam klasifikasi plastik sehingga styrofoam lebih berbahaya dibandingkan plastik yang lainnya karena sulitnya terurai di alam. Metode yang digunakan untuk menangani limbah styrofoam yang hanya dilakukan dengan pembuangan akan membebani alam dalam proses penguraiannya (Fitidarini and Damanhuri, 2011). Metode lain yang bersifat ramah lingkungan diperlukan untuk mengurangi limbah Styrofoam. Metode yang dapat dilakukan salah satunya adalah melalui proses biodegradasi yang memanfaatkan mikroorganisme seperti jamur dan bakteri yang berperan dalam penguraian polimer alam maupun polimer sintetis.

Biodegradasi merupakan proses dimana bahan organik dipecah oleh bakteri dan jamur. Proses biodegradasi polimer berdasarkan aktivitas enzimnya, dibagi menjadi dua kategori yaitu depolimerase ekstraseluler dan intraseluler. Eksoenzim dari bakteri akan memecah polimer menjadi oligomer, dimer, atau monomer yang dapat melewati membran semipermiabel bakteri dan akan dimanfaatkan sebagai sumber karbon hingga bakteri menghasilkan produk akhir metabolismenya yaitu $\mathrm{CO}_{2}$ dan $\mathrm{H}_{2} \mathrm{O}$ (Pramila and Ramesh, 2015).

Mikroorganisme memiliki peran penting pada proses biodegradasi di lingkungan. Bakteri merupakan mikroorganisme yang paling dominan dan hampir separuh dari biomassa mikroba pada tanah adalah bakteri. Sumber potensial ditemukannya bakteri indigenous yang dapat mendegradasi polimer sintetik adalah di Tempat Pembuangan Akhir atau TPA. Daerah TPA ditemukan banyak sampah, baik sampah organik yang busuk karena lama tertimbun maupun sampah anorganik termasuk Styrofoam.

Jenis bakteri yang diketahui dapat mendegradasi polimer sintetik diantaranya adalah Pseudomonas spp., Bacillus spp., Staphylocoocus sp., Mycobacterium sp., dan Streptomyces sp. (Kanaly and Harayama, 2000). Genus bakteri pendegradasi polimer sintetik yang berhasil di identifikasi dari Tanah TPA Bengkala Kab. Buleleng didapatkan 10 genus bakteri, yaitu: Acetobacter, Paracoccus, Bacillus, Agrobacterium, Zooglea, Lactobacillus, Alcaligenes, Acinetobacter, Microbacterium dan Carnobacterium (Ristiati, Suryanti and Indrawan, 2018).

Metode yang dapat dilakukan untuk mendeteksi proses biodegradasi Styrofoam yaitu dengan metode Kolom Winogradsky. Metode ini menciptakan lingkungan yang dapat menekan konsorsium mikroorganisme untuk membentuk biofilm. Pembentukan biofilm tersebut dapat menunjukkan bahwa terdapat pertumbuhan bakteri yang berperan dalam proses biodegradasi.

\section{METODOLOGI PENELITIAN}

Penelitian ini menggunakan metode eksploratif deskriptif yang terdiri atas tahapan uji biodegradasi dengan metode Kolom Winogradsky, isolasi dengan teknik pour platedan identifikasi bakteri pendegradasi Styrofoam. Objek yang digunakan adalah Tanah TPA yang diambil dari TPA Sarimukti Cipatat Bandung dan Sampel Styrofoam kemasan makanan yang dijual di pasaran.

\section{Material}

Bahan yang digunakan yaitu medium Mineral Salt Medium (MSM), medium Nutrient Agar (NA), akuades steril, alkohol 70\%, dan $\mathrm{NaCl}$ fisiologis $0,9 \%$.

Alat yang digunakan dalam penelitian ini adalah alat yang umum digunakan di laboratorium, mikroskop Binokuler Tipe CX-31 Olympus, dan Vitex 2 Compact Biomerieux.

\section{Pengambilan Sampel Tanah}

Sampel tanah diambil dari lahan timbunan sampah yang berlokasi di TPA Sarimukti Cipatat Bandung, dengan metode komposit pola acak dengan 10 titik dan kedalaman tanah 3-5 $\mathrm{cm}$. Pengambilan titik sampel dilakukan berdasarkan terdapatnya styrofoam yang sudah tertimbun dan mulai terurai. 


\section{Persiapan Sampel Styrofoam}

Styrofoam dipotong dengan ukuran $2 \times 2 \mathrm{~cm}$ dan direndam alkohol $70 \%$ selama 30 menit. Styrofoam dikeringkan di bawah UV pada Laminar Air Flow.

Uji Biodegradasi

Botol diisi sampel tanah dan medium Mineral Salt Medium (MSM) (1:1). Styrofoam dimasukkan ke dalam medium hingga terendam dalam medium. Botol ditutup dan diinkubasi pada suhu ruangan selama 8 minggu.

\section{Isolasi Bakteri Pendegradasi Styrofoam}

Isolasi bakteri pendegradasi styrofoam dilakukan dengan metode pengenceran berseri dan dilanjutkan dengan metode pour plate. Potongan styrofoam diambil dari botol setiap minggu. Potongan styrofoam dihomogenkan dengan vortex dengan kecepatan 2000 rpm selama 30 detik tiap 5 kali. Inokulum diambil 1 $\mathrm{mL}$ dan dilakukan pengenceran hingga pengenceran $10^{-7}$. Tiga pengenceran terakhir dimasukkan ke dalam cawan petri dan dimasukkan medium Nutrient Agar (NA), lalu diinkubasi selama 24 jam pada suhu $37^{\circ} \mathrm{C}$.

Identifikasi Bakteri Pendegradasi Styrofoam:

a. Pengamatan Makroskopis Koloni Bakteri

Pada pengamatan makroskopis, koloni bakteri dilihat morfologi makroskopis diantaranya adalah bentuk, warna, elevasi, pinggiran, dan permukaan koloni bakteri.

b. Pengamatan Mikroskopis Sel Bakteri

Biakan bakteri yang berumur 24 jam dilakukan pewarnaan Gram dan diamati di bawah mikroskop dengan perbesaran 1000x. Bakteri Gram positif akan berwarna ungu dan bakteri Gram negatif akan berwarna merah.

c. Identifikasi secara Biokimia

Uji biokimia untuk identifikasi bakteri dilakukan dengan menggunakan alat Vitex. Isolat bakteri diambil 1 ose dan dipindahkan dalam tabung reaksi yang berisi $3 \mathrm{ml} \mathrm{NaCl}$ fisiologis steril dan disesuaikan dengan ketentuan Mc Farland, lalu diletakkan pada kaset kartu yang sesuai. Password dan data uji dimasukkan dalam sistem komputer. Kaset yang telah berisi kartu dimasukkan ke dalam ruang vacum dan dipindahkan ke dalam ruang pemotongan dan pembacaan. Bakteri otomatis akan teridentifikasi dari hasil uji biokimia tersebut.

\section{HASIL DAN PEMBAHASAN}

Metode kolom Winogradsky digunakan untuk pengujian biodegradasi. Metode ini dapat menunjukkan gambaran ekologis bakteri tanah pada suatu ekosistem dan stratifikasi donor elektron pada tiap lapisan. Metode kolom Winogradsky menggunakan botol yang diisi dengan tanah dari TPA dan medium MSM (1:1) serta dimasukan sampel styrofoam.

\section{Hasil Uji Biodegradasi}

Tanah merupakan sumber potensial untuk bakteri yang dapat mendegradasi polimer karena sebagian besar bakteri dari tanah TPA telah beradaptasi dengan lingkungannya yang memiliki banyak limbah organik dan anorganik termasuk styrofoam. Medium MSM digunakan sebagai media nutrisi tanpa sumber karbon untuk menumbuhkan bakteri, maka diharapkan bakteri tersebut akan menggunakan sumber karbon dari styrofoam.

Pemakaian styrofoam sebagai kemasan untuk makanan memiliki kelebihan dan kekurangan. Kelebihan penggunaan styrofoam untuk kemasan makanan adalah dapat mencegah kebocoran, bisa mempertahankan suhu panas ataupun dingin, mempertahankan kesegaran dan keutuhan makanan yang dikemas, biaya murah, serta bentuknya ringan. Namun, ternyata styrofoam juga memiliki kekurangan yaitu kemungkinan terjadinya migrasi atau berpindahnya zat berbahaya dari styrofoam ke dalam makanan, terutama jika makanan tersebut tidak cocok dengan styrofoam.

Migrasi zat berbahaya ini dapat terjadi karena dipengaruhi oleh beberapa faktor, diantaranya yaitu suhu makanan, lama penyimpanan dan proses pengolahannya. Semakin tinggi suhu makanan tersebut, maka semakin banyak monomer zat berbahaya yang dapat bermigrasi ke dalam makanan. Semakin lama kontak antara makanan dan styrofoam tersebut, maka jumlah zat yang bermigrasi dapat semakin tinggi.

Limbah styrofoam dapat bertahan hingga bertahun-tahun sehingga menyebabkan pencemaran terhadap lingkungan. Pengolahan limbah styrofoam dengan cara dibakar akan menghasilkan gas yang akan mencemari udara dan membahayakan pernapasan manusia, dan jika ditimbun dalam tanah maka akan mencemari tanah dan air tanah. 
Selain itu faktor yang menyebabkan rusaknya lingkungan adalah faktor pembuangan limbah sampah plastik karena dibutuhkan waktu 1000 tahun agar styrofoam dapat terurai oleh tanah secara terdekomposisi atau terurai dengan sempurna. Saat terurai pun, partikel-partikel dari styrofoam akan mencemari tanah dan air tanah.

Styrofoam jadi berbahaya karena terbuat dari butiran-butiran styrene, yang diproses dengan menggunakan benzena. Jika styrofoam digunakan sebagai kemasan bagi makanan atau minuman, bahan kimia berbahaya yang terkandung dalam styrofoam akan berpindah ke makanan atau minuman yang dikemasnya. Perpindahannya akan semakin cepat jika kadar lemak (fat) dalam suatu makanan atau minuman makin tinggi. Selain itu, minuman yang mengandung alkohol atau asam juga dapat mempercepat laju perpindahan (Irawan dan Supeni, 2013).

Bakteri akan memecah polimer menjadi monomer yang digunakan dalam metabolismenya untuk menghasilkan sumber energi. Biodegradasi dapat terjadi karena adanya kerjasama antar bakteri yang dapat mendegradasi polistiren. Bakteri menghasilkan enzim spesifik yang dapat memecah polistiren menjadi monomer stiren yang lebih sederhana. Proses penguraian ini ramah lingkungan karena bakteri tidak akan menghasilkan senyawa berbahaya ketika mengurai polistiren. Pembentukan biofilm bakteri pada permukaan Styrofoam menandakan adanya pertumbuhan bakteri pendegradasi yang menggunakan polistiren untuk metabolismenya.

\section{Hasil Isolasi dan Identifikasi Bakteri}

Spesies bakteri berdasarkan fungsinya secara simbiotik dianggap sebagai konsorsium. Para peneliti sedang mengeksplorasi potensi dan pemrograman ulang fungsi dari konsorsium bakteri untuk pendekatan spesifik, terutama untuk bioremediasi kontaminan (Dangi et al., 2019). Konsorsium bakteri dapat melakukan lebih dari satu tugas dalam satu populasi (Villaverde et al., 2017). Biodegradasi polimer sintetis membutuhkan mineralisasi lengkap yang dijalankan oleh berbagai enzim dan jalur sintetiknya yang biasanya tidak ada dalam satu strain bakteri dan mudah dilakukan oleh konsorsium. Dalam beberapa waktu terakhir, konsorsium bakteri telah banyak terlibat dalam proses degradasi polimer sintetis, contohnya adalah kultur campuran dari Lysinibacillus xylanilyticus dan Aspergillus niger yang diisolasi dari tanah TPA Teheran, digunakan untuk mendegradasi Low Density Polyethylene (LDPE) (Jaiswal et al., 2020).

Hasil isolasi dan identifikasi bakteri dalam penelitian ini diperoleh 4 spesies bakteri, yaitu Pseudomonas aeruginosa, Bacillus amyloliquefaciens, Bacillus cereus dan Bacillus firmus. Karakteristik makroskopis bakteri pendegradasi ini diamati secara langsung berdasarkan bentuk, warna, elevasi, pinggiran dan permukaan koloni.

\section{a. P. aeruginosa}

Bakteri $P$. aeruginosa memiliki ciri koloni yaitu bentuk bulat, warna kemerahan, elevasi cembung, pinggiran rata dan permukaan berlendir (Gambar 1). Selain itu, P. aeruginosa juga memiliki kemampuan menghasilkan pigmen hijau-kebiruan dan mengakibatkan medium NA berubah warna dan koloni terlihat berwarna hijau saat di bawah sinar UV. Karakteristik mikroskopis bakteri ini yaitu tergolong pada bakteri Gram negatif dan memiliki bentuk sel batang (Gambar 2).

$P$. aeruginosa adalah bakteri basil Gram negatif yang banyak ditemukan di alam, tanah dan air. Diklasifikasikan sebagai patogen oportunistik, $\quad P$. aeruginosa jarang menyebabkan penyakit pada host normal tetapi merupakan penyebab utama infeksi pada pasien dengan kondisi yang mendukung untuk terinfeksi bakteri ini.

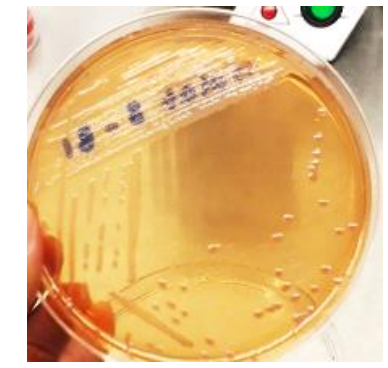

Gambar 1.

Makroskopis

$P$. aeruginosa

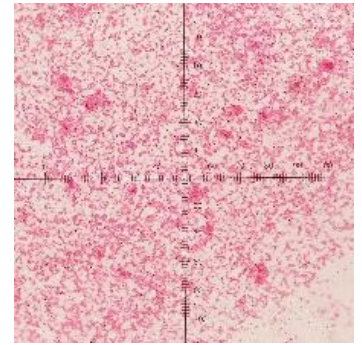

Gambar 2.

Mikroskopis

$P$. aeruginosa

$(\mathrm{P}=1000 \times)$
$P$. aeruginosa memiliki kemampuan untuk dapat beradaptasi dengan kondisi yang tidak dapat ditoleransi oleh organisme lainnya. Bakteri ini tidak memfermentasi laktosa atau karbohidrat lain tetapi dapat mengoksidasi glukosa dan xilosa. Tumbuh secara aerobik atau anaerob jika nitrat tersedia sebagai akseptor elektron anorganik, seperti halnya di paru-paru pasien dengan cystic fibrosis (CF). Sebagian 
besar strain $P$. aeruginosa menghasilkan satu atau lebih pigmen, termasuk pyocyanin (biruhijau), pyoverdine (kuning-hijau dan fluoresen), dan pyorubin (merah-coklat) (Planet, 2017).

Identifikasi secara biokomiawi dengan alat vitex didapatkan spesies $P$. aeruginosa setelah dilakukan analisis selama 6,82 jam, dengan probabilitas 99\%. Detail biokimia yang positif pada spesies ini pada kartu GN adalah AGLTp, dGLU, GGT, dMAN, dMNE, BAIap, ProA, TyrA, CIT, MNT, ILATk, SUCT, CMT, O129R, IMLTa, dan ILATa.

\section{b. B. amyloliquefaciens}

B. amyloliquefaciens memiliki ciri koloni yaitu bentuknya bulat, berwarna putih, elevasi rata, pinggiran bergerigi halus dan permukaan tidak berlendir (Gambar 3). Karakteristik mikroskopis yang dimiliki bakteri ini adalah tergolong dalam bakteri Gram positif dan berbentuk batang (Gambar 4).

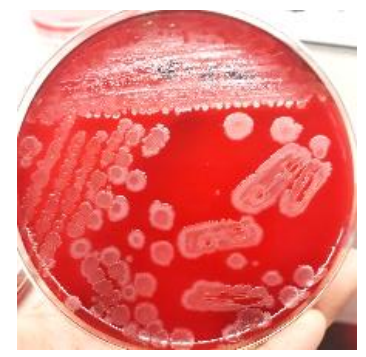

Gambar 3.

Makroskopis

B. amyloliquefaciens

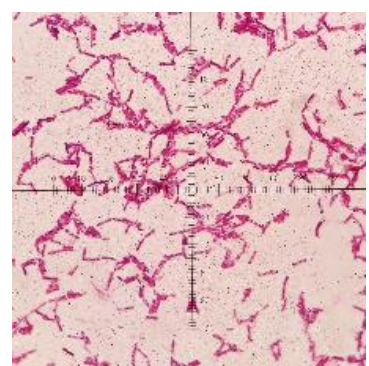

Gambar 4.

Mikroskopis

B. amyloliquefaciens

$(\mathrm{P}=1000 \times)$
B. amyloliquefaciens adalah bakteri gram positif dan pembentuk spora yang aktif di zona akar tanah, dan umum ditemukan di ekosistem tanah (Siemering et al., 2016). Bakteri B. amyloliquefaciens menghasilkan endospore berbentuk oval, termasuk bakteri aerob dan mampu memfermentasi gula, tetapi dapat tumbuh pada keadaan anaerob apabila terdapat glukosa dan nitrat sebagai akseptor elektron (Baruzzi et al., 2011).

Identifikasi secara biokomiawi dengan alat vitex didapatkan spesies $B$. amyloliquefaciens setelah dilakukan analisis selama 13,90 jam, dengan probabilitas $90 \%$. Detail biokimia yang positif pada spesies ini pada kartu BCL adalah LeuA, PheA, BGAL, PyrA, AGAL, TyrA, APPA, INO, MdG, MTE, GlyA, dMNE, PLE, BGLU, PVATE, dTRE,
INU, dGLU, dRIB, NaCl 6.5\%, KAN, ESC, dan TTZ.

\section{c. B. cereus}

B. cereus memiliki karakteristik makroskopis dengan bentuk tidak beraturan, berwarna putih pucat, elevasi rata, pinggirannya bergerigi halus dan permukaan koloninya tidak berlendir (Gambar 5). Adapun Karakteristik mikroskopisnya yaitu tergolong dalam bakteri Gram positif dan berbentuk batang (Gambar 6).

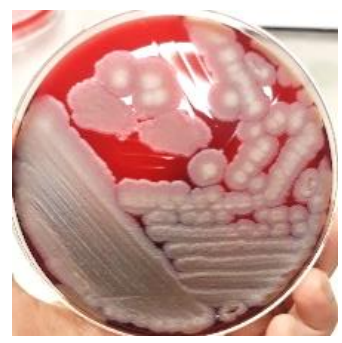

Gambar 5.

Makroskopis B. cereus

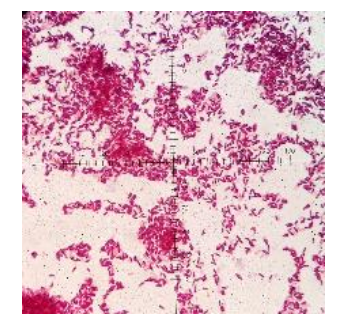

Gambar 6.

Mikroskopis

B. cereus

$(\mathrm{P}=1000 \times)$
Bacillus cereus adalah bakteri anaerob fakultatif Gram-positif, berbentuk batang, yang dapat menghasilkan racun yang menyebabkan keracunan makanan. Bakteri ini membentuk endospora pelindung, aktivitas beta hemolitik, dan motil. B. cereus menyebabkan dua jenis penyakit; emetik (mual dan muntah) dan diare. Dosis infeksi $B$. cereus umumnya dikaitkan dengan konsumsi $10^{5}-10^{8}$ organisme. Dosis ini dapat bervariasi tergantung pada jumlah enterotoksin yang dihasilkan oleh bakteri tersebut. B. cereus tersebar luas di lingkungan dan dapat diisolasi dari tanah dan tumbuhan, dapat ditemukan dalam berbagai makanan termasuk nasi dan pati lainnya; makanan siap saji seperti sup, saus dan puding; susu, daging, dan sayuran (Osborne, 2013).

Identifikasi secara biokomiawi dengan alat vitex didapatkan spesies $B$. cereus setelah dilakukan analisis selama 13,88 jam, dengan probabalitas $86 \%$. Detail biokimia yang positif pada spesies ini pada kartu BCL adalah LeuA, PheA, PyrA, TyrA, BNAG, APPA, ELLM, GlyA, dMNE, NAG, BGLU, dTRE, dGLU, dRIB, $\mathrm{NaCl} 6,5 \%$, KAN, ESC, dan POLYB_R.

\section{d. B. firmus}

B. firmus memiliki karakteristik makroskopis dengan bentuk bulat, warna kekuningan, elevasi koloni rata, pinggiran 
koloni rata dan permukaan koloni bakterinya berlendir (Gambar 7). Karakteristik mikroskopis dari bakteri ini yaitu tergolong ke dalam bakteri Gram positif dan berbentuk batang (Gambar 8).

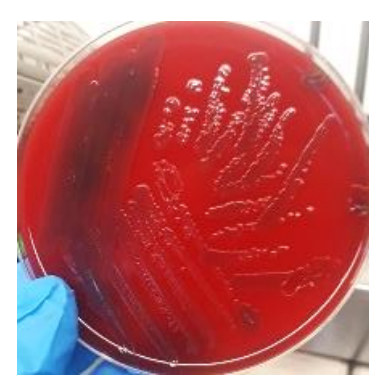

Gambar 7.

Makroskopis

B. firmus

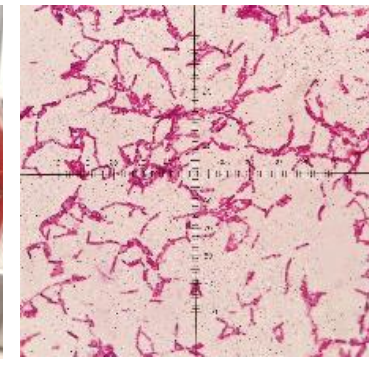

Gambar 8.

Mikroskopis

B. firmus

$(\mathrm{P}=1000 \times)$
Bacillus firmus adalah bakteri dengan koloni kecil, semi-transparan, rata, Gram positif, basil, pembentukan spora, katalase positif dan motil (Anonim, 2011).

Identifikasi secara biokomiawi dengan alat vitex didapatkan spesies $B$. firmus setelah dilakukan analisis selama 13,83 jam, dengan probabilitas $95 \%$. Detail biokimia yang positif pada spesies ini pada kartu BCL adalah AspA, LeuA, PheA, PyrA, AlaA, TyrA, APPA, ELLM, GlyA, AGLU, dGLU, KAN, dan TTZ.

Mohan et al., (2016) melaporkan potensi Pseudomonas sp. dan Bacillus sp. untuk mendegradasi Brominated High-Impact Polystyrene. Sedangkan menurut (Ghosh et al., 2013), bakteri pengurai polimer lainnya termasuk Pseudomonas stutzeri, Alcaligenes faecalis, Pseudomonas putida, Brevibacillus borstelensis, Streptomyces sp., dan Staphylococcus sp., Brevibacillus borstelensis, Rhodococcus rubber, Pseudomonas chlororaphis, dan Comamonas acidovorans TB35.

\section{SIMPULAN}

Hasil yang didapat pada penelitian ini terdapatnya biofilm bakteri yang tumbuh di permukaan Styrofoam. Hasil isolasi dan identifikasi bakteri didapatkan 4 spesies bakteri pendegradasi Styrofoam, yaitu $B$. amyloliquefaciens, B. cereus, B. firmus dan $P$. aeruginosa. Hasil dari penelitian ini dapat direkomendasikan untuk dikembangkan sebagai metode untuk mengurangi limbah Styrofoam yang ramah lingkungan.

\section{UCAPAN TERIMA KASIH}

Terima kasih kepada Kementrian Riset, Teknologi, dan Pendidikan Tinggi yang telah memberikan bantuan dana Hibah Penelitian Dasar Unggulan Perguruan Tinggi.

\section{REFERENSI}

Baruzzi, F. et al. (2011) 'Antimicrobial compounds produced by Bacillus spp. and applications in food', Communicating Current Research and Educational Topics and Trends in Applied Microbiology,A. Méndez-Vilas (Ed.), (January), pp. 1102-1111. Available at: http://www.formatex.info/microbiology3 /book/1102-1111.pdf.

Dangi, A. K. et al. (2019) 'Bioremediation through microbes: systems biology and metabolic engineering approach', Critical Reviews in Biotechnology. Taylor \& Francis, 39(1), pp. 79-98. doi: 10.1080/07388551.2018.1500997.

Fitidarini, N. L. and Damanhuri, E. (2011) 'Timbulan Sampah Styrofoam di Kota Bandung', Jurnal Teknik Lingkungan, 17(2), pp. 87-97.

Ghosh, S. K., Pal, S. and Ray, S. (2013) 'Study of microbes having potentiality for biodegradation of plastics.', Environmental science and pollution research international, 20(7), pp. 43394355. doi: 10.1007/s11356-013-1706-x.

Irawan, S. and Supeni, G. (2013) 'Karakteristik migrasi kemasan dan peralatan rumah tangga berbasis polimer', Jurnal Kimia dan Kemasan, 35(2), p. 105. doi: 10.24817/jkk.v35i2.1881.

Jaiswal, S., Sharma, B. and Shukla, P. (2020) 'Integrated approaches in microbial degradation of plastics', Environmental Technology and Innovation. Elsevier B.V., 17, pp. 1-53. doi: 10.1016/j.eti.2019.100567.

Kanaly, R. A. and Harayama, S. (2000) 'Biodegradation of High-MolecularWeight Polycyclic Aromatic Hydrocarbons by Bacteria', journal of bacteriology, 182(8), pp. 2059-2067.

Mohan, A. J. et al. (2016) 'Microbial assisted High Impact Polystyrene (HIPS) degradation', Bioresource Technology. Elsevier Ltd, 213, pp. 204-207. doi: 10.1016/j.biortech.2016.03.021. 
Osborne, N. (2013). Fact Sheet on Bacillus cereus.

https://www.thermofisher.com/blog/food /fact-sheet-on-bacillus-cereus/ Diakses tanggal 10 Desember 2019.

Planet, P. J. (2017) Pseudomonas aeruginosa. Fifth Edit, Principles and Practice of Pediatric Infectious Diseases. Fifth Edit. Elsevier Inc. doi: 10.1016/B978-0-32340181-4.00155-9.

Pramila, R. and Ramesh, K. V. (2015) 'Potential biodegradation of low density polyethylene (LDPE) by Acinetobacter baumannii', African Journal of Bacteriology Research, 7(3), pp. 24-28. doi: 10.5897/JBR2015.0152.

Ristiati, N. P., Suryanti, I. A. P. and Indrawan, I. M. Y. (2018) 'Isolasi Dan Karakterisasi Bakteri Tanah Pada Tempat Pemrosesan Akhir Di Desa Bengkala Kabupaten Buleleng', Jurnal Matematika, Sains, dan Pembelajarannya, 12(1), pp. 64-77.

Siemering, G., Ruark, M. and Gevens, A. (2016) 'The value of Bacillus amyloliquefaciens for crop production', University of Wisconsin- Extension, A4114-3, pp. 1-4. doi: 10.1186/1475-2859-8-63.

Sulchan, M. and Nur, E. (2007) 'Keamanan Pangan Kemasan Plastik dan Styrofoam', Maj Kedokt Indon, 57(2), pp. 54-59.

Villaverde, J. et al. (2017) 'Bioremediation of diuron contaminated soils by a novel degrading microbial consortium', Journal of Environmental Management, 188, pp. 379-386.

doi: 10.1016/j.jenvman.2016.12.020. 